1

\title{
GDH activity and ammonium excretion in the marine mysid, Leptomysis lingvura: effects of age and starvation
}

\author{
I. Fernández-Urruzola, T.T. Packard, M. Gómez \\ Biological Oceanography Laboratory, Facultad de Ciencias del Mar, Universidad de Las \\ Palmas de Gran Canaria. Campus Universitario de Tafira, 35017, Las Palmas de Gran \\ Canaria, Spain.
}

\begin{abstract}
Ammonium $\left(\mathrm{NH}_{4}^{+}\right)$release by bacterial remineralization and heterotrophic grazers is the largest recycled nitrogen source in the euphotic zone. It determines the regenerated fraction of phytoplankton productivity, so the measurement of $\mathrm{NH}_{4}^{+}$excretion in marine organisms is necessary to characterize both the magnitude and the efficiency of the nitrogen cycle. Glutamate dehydrogenase $(\mathrm{GDH})$ is largely responsible for $\mathrm{NH}_{4}^{+}$formation in crustaceans and consequently should be useful in estimating $\mathrm{NH}_{4}^{+}$excretion by marine zooplankton. Here, we study the physiological rate of $\mathrm{NH}_{4}^{+}$excretion and the GDH activity in an important North Atlantic mysid, Leptomysis lingvura. We address body size and starvation as sources of variability on the GDH to $\mathrm{NH}_{4}^{+}$excretion ratio $\left(\mathrm{GDH} / \mathrm{R}_{\mathrm{NH}_{4}+}\right)$.

We found a strong correlation between the $\mathrm{R}_{\mathrm{NH}_{4}+}$ and the GDH activity $\left(\mathrm{r}^{2}=0.87, \mathrm{n}=41\right)$ during growth. Both variables were regressed against protein in order to obtain the allometric scaling exponent. Since GDH activity maintained a linear relation $(\mathrm{b}=0.93)$ and $\mathrm{R}_{N H_{4}}+$ scaled exponentially $(\mathrm{b}=$
\end{abstract}

\footnotetext{
*Corresponding author. Tel.: +34 9284545 46; fax: +34 928452922

Email address: ifernandez@becarios.ulpgc.es (I. Fernández-Urruzola)
} 
$0.55)$ in well fed mysids, the $\mathrm{GDH} / \mathrm{R}_{\mathrm{NH}_{4}}+$ ratio increased with size. However, the magnitude of its variation increased even more when adult mysids were starved. In this case, the $\mathrm{GDH} / \mathrm{R}_{\mathrm{NH}_{4}}+$ ratio ranged from 11.23 to 102.41.

Keywords: GDH, ammonium regeneration, L. lingvura, starvation, body size.

\section{Introduction}

Nitrogen is essential for life. It is constituent to many biological structures and in all enzymatic reactions, but its availability is frequently limited in ocean ecosystems. As a result, nitrogen plays a critical role in biogeochemical cycles (Falkowski et al., 1998). Despite its existence in multiple oxidation states and in many chemical compounds in the ocean, the nitrogen which supports primary production occurs mainly in the forms of ammonium and nitrate (Bronk et al., 1994; Yool et al., 2007). The availability of these compounds determines the productivity of the ocean and thus, the capacity of this huge ecosystem to act as a carbon dioxide sink. Ammonium $\left(\mathrm{NH}_{4}^{+}\right)$ excretion from glutamate deamination in heterotrophic organisms constitutes an important recycled nitrogen source in the euphotic zone (Harrison et al., 1987; Steinberg and Saba, 2008), even though the nitrate remineralized in the near-surface mixed layer also sustains the regenerated production (Zehr and Ward, 2002; Beckmann and Hense, 2009; Zehr and Kudela, 2011). However, the nitrate produced in deep waters via nitrification, once it reaches the surface by vertical transport, is largely responsible for new production (Dugdale and Goering, 1967; Eppley and Peterson, 1979).

The relevance of the regenerated nitrogen to the phytoplanktonic growth 
rate and biomass has been widely addressed in the literature. The heterotrophic $\mathrm{NH}_{4}^{+}$release, on average, supplies around $80 \%$ of the primary producers' requirements (Harrison, 1992), which reflects the significance of this metabolic process at a global scale. Factors such as temperature (Ikeda, 1985), nutritional composition of ingested food (Glibert, 1993; Miller and Roman, 2008; Saba et al., 2009) and the interaction between the different trophic levels (Glibert, 1998), among others, can modify locally this percentage. As a consequence, ammonium recycling efficiencies range from $50 \%$ in coastal waters to about $95 \%$ in the less productive areas of tropical latitudes (Eppley and Peterson, 1979), with the mesozooplankton responsible for $12 \%$ to $33 \%$ (Atkinson and Whitehouse, 2001; Hernández-León et al., 2008). Quantifying this physiological process in the oceans is then, necessary to characterize the efficiency of the nitrogen cycle and to understand the basis of an aquatic ecosystem's productivity.

In order to assess the $\mathrm{NH}_{4}^{+}$excretion in zooplankton, water bottle-incubations and the more sensitive ${ }^{15} \mathrm{~N}$ isotope dilution technique have been used by oceanographers (Glibert et al., 1982; Steinberg and Saba, 2008; Alcaraz et al., 2010). However, although direct, these delicate methods are complicated by artifacts derived from organism manipulation, overcrowding or starvation that may occur during long incubation times (Bidigare, 1983). On a physiological scale such measurements can be made, but at a low data acquisition rate. This is fine for physiology, but oceanography requires many measurements made over large time and space scales and so a high data acquisition rate is needed. In recognizing these requirements of oceanography, Bidigare and King (1981) introduced a biochemical approach by proposing the en- 
zyme glutamate dehydrogenase (GDH) as an index for $\mathrm{NH}_{4}^{+}$formation in the marine systems. They chose GDH because it is found in high levels in planktonic crustaceans and because its role in amino acid catabolism argues for its control over a great proportion of $\mathrm{NH}_{4}^{+}$excretion. In these ammoniotelic organisms, proteins are decomposed to amino acids and then, transaminated with $\alpha$-ketoglutarate to produce $\alpha$ - ketoacids and glutamate. The glutamate is oxidized by NAD-dependent GDH (EC 1.4.1.3) into $\mathrm{NH}_{4}^{+}$, NADH, $\alpha$ - ketoglutarate and one proton. Thus, the potential $\mathrm{NH}_{4}^{+}$excretion can be calculated from the rate of the GDH reaction (i.e., GDH activity).

The interest in GDH persists in spite of the problems associated with using enzyme assays to predict the physiology of the organisms. First of all, enzyme analyses are classically designed to measure the $\mathrm{V}_{\max }$ of an enzyme reaction. Accordingly, an enzyme assay requires the addition of externally added substrate, which insures that the assay determines the potential enzymatic activity $\left(\mathrm{V}_{\max }\right)$ instead of some undefinable other level of activity. It would be desirable to measure the actual rate of activity in the sample, the in vivo rate, but the technology is just not available now. Thus, any enzyme, under unlimited substrates, operates at its maximum rate, and the product generated over time is simply a function of the amount of enzyme present. In addition, there is variability in the ratios of GDH activity to $\mathrm{NH}_{4}^{+}$excretion due to changes in specific composition, body size and trophic conditions. How these parameters impact the biochemistry and physiology of $\mathrm{NH}_{4}^{+}$excretion is part of this investigation. In spite of these uncertainties, at an operational level, the GDH analysis is a simple, fast and inexpensive proxy for heterotrophic $\mathrm{NH}_{4}^{+}$release. Strengthening our knowledge of the 
relationship between GDH activities and the $\mathrm{NH}_{4}^{+}$excretion rates $\left(\mathrm{R}_{\mathrm{NH}_{4}}\right)$ under different conditions, would lead to more meaningful interpretations of the mesoscale variations in planktonic $\mathrm{NH}_{4}^{+}$excretion.

Working with the marine mysid Praunus flexuosus, Bidigare and King (1981) established a high correlation $\left(\mathrm{r}^{2}=0.92, \mathrm{n}=7\right)$ between GDH activity and the production of the main nitrogenous waste of crustaceans, $\mathrm{NH}_{4}^{+}$ (Regnault, 1987; Ikeda et al., 2000). These results were confirmed in mixed communities of zooplankton by Park et al. $(1986)\left(r^{2}=0.98, n=10\right)$, with a relative small range of variation in their $\mathrm{GDH}$ to $\mathrm{NH}_{4}^{+}$excretion ratio (18.18 \pm 6.72 ). However, this ratio is expected to vary according to the body size and nutritional status since GDH is a regulatory enzyme which is modulated by the allosteric effectors adenosine diphosphate (ADP) and guanosine triphosphate (GTP). As a consequence, Park (1986) obtained substantial fluctuations in the GDH/ $\mathrm{R}_{\mathrm{NH}_{4}{ }^{+}}(36.92 \pm 29.9)$ for two species of copepods, when food availability conditions were modified during the experimentation. Similar behavior on that relationship (values from 1.2 to $42.5, \mathrm{n}=59$ ) was described by Hernández-León and Torres (1997) on mixed zooplankton from waters around Gran Canaria, where the so-called "late winter bloom" changes the trophic situation. These authors demonstrated a significant correlation between the GDH/ $\mathrm{R}_{N_{4}+}$ and respiration to excretion $\left(\mathrm{R}_{\mathrm{O}_{2}} / \mathrm{R}_{\mathrm{NH}_{4}}\right)$ ratios, since the amount of $\mathrm{NH}_{4}^{+}$excreted is determined by the nitrogen content of the metabolized matter required for energy. In addition, Berges et al. (1993) pointed out the necessity of considering that enzyme activities scale allometrically with body mass in order to avoid erroneous interpretation of data when size structure of population is different. However, no attempt has 
been made to determine the influence of biomass scaling in both GDH and $\mathrm{NH}_{4}^{+}$excretion. If GDH is used as $\mathrm{NH}_{4}^{+}$excretion proxy, then it should follow equivalent size dependence.

Here, we address the issue of age and starvation as sources of variation in the relationship between $\mathrm{GDH}$ activity and $\mathrm{NH}_{4}^{+}$excretion in the mysid shrimp Leptomysis lingvura. We chose L. lingvura because of its widespread distribution in shallow marine waters around Canary Islands, which implies a significant role in the nitrogen cycle of the coastal ecosystem. Furthermore, our choice is strengthened by the arguments that mysids are critical in nutrient cycling and selective grazing in the near coastal environments (Lindén and Kuosa, 2004). The main objective of this research is to provide better biochemical insight into L. lingvura's nitrogen metabolism, which might be controlled under different physiological conditions by fluctuations in the glutamate pool and by allosteric regulation of GDH. Furthermore, we introduce spectrofluorometry as a technique for increasing the sensibility of the GDH assay in zooplankton and hence, decreasing the biomass needed for a successful analysis.

\section{Material and Methods}

\subsection{Location and Sampling}

Marine mysids were sampled by diving off the Risco Verde coast (27 $51^{\prime} 26^{\prime \prime}$ N, 15'23'11" W), located in the south-east of Gran Canaria island. The zooplankters were collected over shallow sandy bottoms, between $8-12 \mathrm{~m}$ depth. Along with each sample, in situ temperature was recorded (19.5 \pm 2 $\left.{ }^{\circ} \mathrm{C}\right)$. Scuba diving equipment, a $500 \mu \mathrm{m}$ mesh size plankton net and plastic 
containers for storing the animals were used for sampling. Three species of mysids were identified: Paramysis nouveli, Siriella armata and Leptomysis lingvura. However, only L. lingvura was used for experimentation because its survival and fertility rates are high in culture (Herrera et al., 2011).

\subsection{Culture conditions}

Once the mysids were captured, they were immediately transferred in 10 L buckets to a culture system constituted by six plastic trays (20 L each) suspended in a circulating water bath. Mysids were cultured as described in Herrera et al. (2011), under a 14:10 ligth:dark cycle and a thermostated temperature $\left(21 \pm 0.5^{\circ} \mathrm{C}\right)$ within the range registered in the sea. Except for starvation experiments, mysids were fed twice daily with $48 \mathrm{~h}$ nauplii of Artemia sp., enriched with Easy-DHA Selco ${ }^{\circledR}$ (INVE, Belgium). Since other studies (Domingues et al., 1998; Lussier et al., 1988) observed cannibalism of the smallest sizes if food became limiting, we provided ad libitum conditions by offering 100 Artemia $\cdot$ organism $^{-1}$ twice per day.

After an acclimation period of $24 \mathrm{~h}$, the healthiest mature mysids were selected and separated in new tanks in order to spawn. The hatchlings collected after one day were used to study the effect of age on physiological rates and GDH activity. For starvation experiments, however, male adults were required, but otherwise the procedures were the same.

\subsection{The influence of age on $\mathrm{NH}_{4}^{+}$excretion and $\mathrm{GDH}$ activity in L. lingvura}

(I) Excretory metabolism. We assessed the impact of body mass on $\mathrm{NH}_{4}^{+}$ excretion and GDH activity during the first thirty days of a mysid cohort, before these organisms became adults. In all the cases, animals were fed 
prior to experimentation. After feeding on Artemia for an hour, mysids were acclimated for half an hour in Whatman $\mathrm{GF} / \mathrm{F}$ filtered seawater. Afterwards, two to six mysids, depending on the biomass, were placed carefully in glass-capped bottles $\left(60 \mathrm{ml}\right.$ each) filled with filtered seawater at $21{ }^{\circ} \mathrm{C}$ and incubated in the dark. All the experiments included one control and three experimental flasks. After 30 minutes, the organisms were immediately transferred to new bottles and the water was siphoned off for $\mathrm{NH}_{4}^{+}$ determination. $\mathrm{NH}_{4}^{+}$was measured spectrofluorometrically according to the Holmes et al. method (1999). It was optimized for the $\mathrm{NH}_{4}^{+}$concentrations expected in this study. The mysid excretion rates were quantified by subtracting the $\mathrm{NH}_{4}^{+}$concentration in control flasks from the $\mathrm{NH}_{4}^{+}$concentration in experimental flask at the end of each incubation period. The procedure was replicated with the same mysids four times over a period of two hours, which revealed the behaviour of these rates. This procedure demonstrated that the rates were constant over these two hours. Furthermore, the short experimental time minimized induction and repression of the mysid's enzyme system as well as minimizing the potential effects of starvation.

(II) GDH assay. Once the incubation experiments ended, mysids were immediately frozen in liquid $\mathrm{N}$ and stored in the freezer $\left(-80^{\circ} \mathrm{C}\right)$ for subsequent GDH analysis and protein determination. Later, the samples were thawed and kept on ice while awaiting analysis in order to prevent a decline in the protein activity. The mysids were placed in $2 \mathrm{ml}$ of sonication medium composed of $100 \mathrm{mM}$ Tris buffer, made up to $\mathrm{pH} 8.6$ with acetic acid. Mysids were then sonicated for 50 seconds at 70\% amplitude in a VXC 130 Sonics device and centrifuged $\left(0-4{ }^{\circ} \mathrm{C}\right)$ for $8 \mathrm{~min}$ at $4000 \mathrm{rpm}$. The supernatant 
fluid was assayed for GDH activity following a slightly modified Bidigare and King (1981) methodology. This modification consisted of using fluorometry rather than spectrophotometry to detect the NADH produced in the GDH reaction. The assay was run on an aliquot of the centrifuged extract (200 $\mu \mathrm{l})$ that was mixed with $\mathrm{NAD}^{+}$and ADP solutions $(300 \mu \mathrm{l}$ and $250 \mu \mathrm{l}$, respectively). Each reagent was made fresh daily and added separately to the mixture, prior to acclimation to the assay temperature. The resultant solution was incubated for a few minutes in a $1 \mathrm{~cm}$ path-length quartz cuvette until no fluctuations in NADH fluorescence were detected. Then, following the addition of glutamate $(500 \mu \mathrm{l})$, the increase of fluorescence was monitored during 2 minutes with a Horiba Jobin Ybon Fluoromax $4{ }^{\circledR}$ spectrofluorometer, at $360 \mathrm{~nm}$ excitation and $460 \mathrm{~nm}$ emission wavelengths. The final volume of the reaction mixture was $1.25 \mathrm{ml}$. It contained $1.2 \mathrm{mM} \mathrm{NAD}^{+}, 2 \mathrm{mM}$ ADP and $50 \mathrm{mM}$ glutamate. Assay temperature was controlled to the in situ temperature $\left(21^{\circ} \mathrm{C}\right)$ by a thermostated multi-cell holder attached to a refrigerated recirculator. The fluorescence units were converted to activities $\left(\mu \mathrm{mol} \mathrm{NH}_{4}^{+} \cdot \mathrm{h}^{-1}\right)$ from the $[\mathrm{NADH}]$-fluorescence standard curve, which was prepared from pure GDH (1.4.1.3) extracted from bovine liver (from SigmaAldrich $\left.{ }^{\circledR}\right)$ for each batch of work. This curve was determined over a range of $0.01-8.6 \cdot 10^{-5}$ international units $(\mathrm{U})$ of $\mathrm{GDH}$ activity $\cdot \mathrm{ml}^{-1}$, where one $\mathrm{U}$ equals the amount of enzyme that converts one $\mu \mathrm{mol} \mathrm{NAD}{ }^{+} \cdot \mathrm{min}^{-1}$. This fluorometric modification was compared with the spectrophotometric assay of Bidigare and King (1981), which is not directly calibrated against GDH activity. It is, instead, based on the specific absortivity for NADH $(\varepsilon=6220$ $\mathrm{M}^{-1} \cdot \mathrm{cm}^{-1}$ ) and Beers-Law. This leads to an apparent overestimation of 
GDH activity by the spectrophotometric assay as is shown in panel $\mathrm{C}$ of Fig. 1, but does not affect its linear relationship with the fluorometric assay.

(III) Biomass and protein determination. Biomass was estimated as protein in the samples using the Lowry method (Lowry et al., 1951) modified by Rutter (1967). Calibration curves were made from standard solutions of bovine serum albumin (BSA), in which absorbance was read at $750 \mathrm{~nm}$ in a Beckman DU 650 spectrophotometer. Each data point represented the mean of triplicate analyses.

\subsection{The impact of starvation on physiological rates and GDH activity in L.} lingvura

A new experimental approach was designed to address the effect of starvation on the biochemistry and the physiology of $\mathrm{NH}_{4}^{+}$excretion in L. lingvura. After acclimating the mysids in the culture system for two days, mature wellfed males were transferred to individual containers. This procedure prevented cannibalism during the experimental period. In the base of each container was a $1 \mathrm{~mm}$ mesh net, which allowed fresh filtered seawater to enter and mysid fecal pellets to exit. During 4 days, successive incubations were carried out in triplicate, using three control bottles in each experiment. $\mathrm{NH}_{4}^{+}$ excretion, GDH activity and protein were assayed as previously described, although apparent Michaelis constants $\left(\mathrm{K}_{m}\right)$ for glutamate were also calculated on each time by classic Lineaweaver-Burk transformation plots. Furthermore, in order to obtain the relationship between the oxygen consumed and the ammonium excreted $\left(\mathrm{R}_{\mathrm{O}_{2}} / \mathrm{R}_{\mathrm{NH}_{4}+}\right), \mathrm{O}_{2}$ consumption rates were estimated in the same incubation experiments by the continuous measurements of dissolved $\mathrm{O}_{2}$ concentrations through a 6-channel Strathkelvin 928 Oxygen System $\AA$ 
respirometer. Mysid respiration rates were calculated from $\mathrm{O}_{2}$ time courses as the difference between the slopes in experimental and control chambers.

\section{Results}

\subsection{GDH analysis and kinetics}

GDH activities were linear over an order of magnitude of biomass (0.014 $0.084 \mathrm{mg}$ protein) for both spectrophotometry and spectrofluorometry (Fig. 1). According to the Student's t-test applied in SPSS ${ }^{\circledR}$ statistics v.19 software, the results showed a high coherence between the mean values of the activities analyzed by the two techniques $(p \geqslant 0.05)$. This fact facilitates the comparison of our data with other data found in the literature. Furthermore, in experiments at the low end of the spectrophotometric range we found that with spectrofluorometry we could read dilutions down to another order of magnitude. In fact, we could detect GDH activity at levels of $3.5 \mu \mathrm{g}$ of protein. In addition, the low standard deviations of the samples quantify the superiority of fluorometry over spectrophotometry in this range.

The dependence of the GDH reaction on the substrates in a well-fed adult L. lingvura is characterized in Fig. 2. Both glutamate and $\mathrm{NAD}^{+}$follow the classic Michaelian hyperbole, where the $\mathrm{V}_{\max }$ was $1.60 \mu \mathrm{mol} \mathrm{NH}_{4}^{+} \cdot \mathrm{h}^{-1} \cdot \mathrm{mg}$ protein $^{-1}$ and $\mathrm{K}_{m}$ was $5.61 \mathrm{mM}$ for glutamate, while for $\mathrm{NAD}^{+}$the $\mathrm{V}_{\text {max }}$ and $\mathrm{K}_{m}$ were $1.97 \mu \mathrm{mol} \mathrm{NH} \mathrm{NH}^{+} \cdot \mathrm{h}^{-1} \cdot \mathrm{mg}$ protein ${ }^{-1}$ and $0.44 \mathrm{mM}$, respectively.

\subsection{The influence of age on $\mathrm{NH}_{4}^{+}$excretion and $\mathrm{GDH}$ activity in L. lingvura} The increases with age of $\mathrm{NH}_{4}^{+}$excretion and GDH activity during the life cycle of L. lingvura (Fig. 3) are consistent with allometric principles. Both 
the physiological rate $\left(\mathrm{r}^{2}=0.83, \mathrm{n}=41\right)$ and the enzyme activity $\left(\mathrm{r}^{2}=0.85\right.$, $\mathrm{n}=41)$ show an exponential trend with age, as well as with protein mass $\left(\mathrm{r}^{2}\right.$ $=0.94, \mathrm{n}=41)$. Statistical analysis based on the non-parametric Spearman's test exhibits a strong correlation of $0.84(\mathrm{p}<0.01)$ between the physiology $\left(\mathrm{R}_{N_{H_{4}}+}\right)$ and the biochemistry $(\mathrm{GDH})$ when both are compared per mysid (Fig. 4). However, this relationship is obscured by protein normalization, so that the correlation becomes less significant $(\mathrm{r}=0.36, \mathrm{p}<0.05)$. Thus, while the normalized $\mathrm{NH}_{4}^{+}$excretion rates decrease with age, GDH activities remain relatively constant (Fig. 5). As a consequence, the GDH activity to ammonium excretion ratio tends to increase slightly $\left(\mathrm{r}^{2}=0.57\right)$ as mysids grow, with an overall value of $9.64 \pm 4.81($ mean $\pm \mathrm{SD})$.

The slope of the regression of the log-transformed data for GDH shows that its activities scale to a global exponent of 0.93 with protein data (Fig. 6 ), which is considerably greater than the scaling exponent registered for the relationship of $\mathrm{NH}_{4}^{+}$excretion with protein (0.55).

\subsection{The influence of starvation on physiological rates and GDH activity}

In contrast to the decrease in the specific $\mathrm{NH}_{4}^{+}$excretion after $10 \mathrm{~h}$ of starvation, the specific GDH activities did not change as the mysids became starved (Fig.7). The GDH activity held a constant value around 1.47 ( \pm 0.54) $\mu \mathrm{mol} \mathrm{NH}_{4}^{+} \cdot \mathrm{h}^{-1} \cdot \mathrm{mg}$ protein ${ }^{-1}$ throughout the entire experiment, so that the GDH/ $\mathrm{R}_{\mathrm{NH}_{4}}+$ ratio, as one would expect, increased. From an initial value of 11.2, it increased almost ten-fold to 102.4 (see table 1). The apparent $\mathrm{K}_{m}$ seemed to increase during the first $26 \mathrm{~h}$ of starvation and then decreased following two days, with a slight increase when the mysids were fed again. In regard to the effect of starvation on the $\mathrm{O}_{2}$ consumption rate, the maximum 
respiration coincided with the highest value registered for $\mathrm{NH}_{4}^{+}$excretion at the level of $10 \mathrm{~h}$ after feeding. Then, there was a decrease of more than six-fold in 1.5 days. Except for the last measurement, the $\mathrm{R}_{\mathrm{O}_{2}} / \mathrm{R}_{\mathrm{NH}_{4}}+$ ratio remainded fairly constant in the range of protein-based metabolism.

\section{Discussion}

\subsection{GDH analysis and kinetics}

Most of the oceanographic research on GDH has been focused on the larger sizes of zooplankton despite the recognition that microzooplankton are the major regenerators of $\mathrm{NH}_{4}^{+}$in marine systems (Bode et al., 2004; Bronk and Steinberg, 2008). The main problem with studying GDH in microzooplankton lies in concentrating them in the field sufficiently to obtain a detectable signal in the spectrophotometer. As a consequence of this difficulty, King et al. (1987) could not evaluate accurately the potential $\mathrm{NH}_{4}^{+}$ regeneration in the fraction of zooplankton below $153 \mu \mathrm{m}$. In this work we have approached the problem by applying the advantages of spectrofluorometry (Segel, 1993) which, by measuring NADH fluorescence, increases the sensitivity of the assay at least six-fold. At low levels of activity, spectrophotometry has difficulty in discriminating between the true GDH signal and background artifacts. This explains the high variability in the spectrophotometric determinations when the enzyme concentrations in the analysis are too low $(\leqslant 0.043 \mathrm{mg}$ protein). On the other hand, high enzyme concentrations $(>0.084 \mathrm{mg}$ protein) quench fluorescence and leads to underestimation of the true signal. This problem, however, can be solved by a simple dilution of the homogenate. Consequently, when available, fluorometry should be su- 
perior to spectrophotometry and here we make the transition to this more sensitive methodology.

The Henri-Michaelis-Menten constant $\left(K_{m}\right)$ for an enzyme is the most important biochemical property of the enzyme that one can measure (Friedmann, 1981). It defines the chemical affinity that the enzyme has for its substrate, the potential control by the substrate over the enzyme reaction, and the approximate concentration of the substrate in the cell (its in vivo concentration). Our $\mathrm{K}_{m}$ estimation for glutamate on well-fed L. lingvura (5.61 $\mathrm{mM}$ ) fall in the range of $\mathrm{K}_{m}$ from other well fed marine zooplankters, i.e., from 2.6 mM (Bidigare and King, 1981) to $11.8 \mathrm{mM}$ (Park, 1986). The dependence of GDH on $\mathrm{NAD}^{+}$has been much less addressed. Batrel and Regnault (1985) have data that indicate a $\mathrm{K}_{m}$ of about $1.3 \mathrm{mM}$, but their measurements were irregular and scantily described. Our $\mathrm{K}_{m}$ for $\mathrm{NAD}^{+}(0.44$ $\mathrm{mM}$ ) is lower and in comparing it with the glutamate $\mathrm{K}_{m}$ of $5.61 \mathrm{mM}$, confirms our finding that the affinity of GDH for $\mathrm{NAD}^{+}$is higher than it is for glutamate. Furthermore, it suggests that the role of $\mathrm{NAD}^{+}$in $\mathrm{GDH}$ control is more important than previously thought. This is consistent with the results described by Jeffries (1969), who did not find pronounced changes in zooplankton glutamate levels over a year. His data imply that in vivo glutamate seems to stay constant through transamination. We conclude from our results that intracellular concentrations of glutamate and $\mathrm{NAD}^{+}$in a well fed L. lingvura are around 5.61 and $0.44 \mathrm{mM}$, respectively.

\subsection{The influence of age on $\mathrm{NH}_{4}^{+}$excretion and GDH activity in L. lingvura} The amount of $\mathrm{NH}_{4}^{+}$excreted by a well-fed adult $L$. lingvura over time $\left(13.9 \pm 1.93 \mu \mathrm{mol} \mathrm{NH}+4 \cdot \mathrm{h}^{-1} \cdot\right.$ ind $\left.^{-1}\right)$ (see Fig. 3B) accords with the rates 


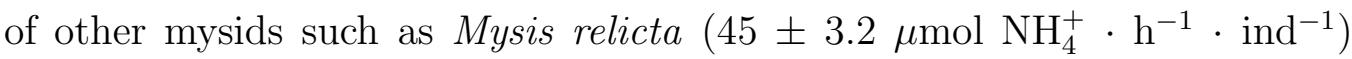
(Lindén and Kuosa, 2004), given the fact that these mysids are about threetimes, or more, the size of the L. lingvura experimented here. Furthermore, the values of GDH activity measured during mysid growth could account for the total $\mathrm{NH}_{4}^{+}$excretion registered at the same time. The high correlation between both parameters suggests an important role for GDH in the nitrogen metabolism, as was argued previously (Bidigare and King, 1981; Park et al., 1986). However, the apparent $\mathrm{NH}_{4}^{+}$excretion at zero GDH activity suggests the participation of other ezymes which also generate $\mathrm{NH}_{4}^{+}$, such as glutaminase and AMP-deaminase. In addition, it is necessary to consider that the $\mathrm{V}_{\text {max }}$ obtained here represents a potential $\mathrm{NH}_{4}^{+}$excretion capacity of more than one order of magnitude greater than the directly measured $\mathrm{NH}_{4}^{+}$excretion rate. Since the substrate concentration required for the theoretical $V_{\max }$ tends to infinity, the actual enzyme velocity (apparent $V_{\max }$ ) measured, in function of the amount of substrate added $(50 \mathrm{mM})$, was around the $90 \%$ of the true $\mathrm{V}_{\text {max }}$, so the difference between the potential and the in vivo rates becomes even bigger. In any case, the slope of the $\mathrm{R}_{\mathrm{NH}_{4}+}$ to GDH activity of 0.054 (Fig. 4) falls between 0.045, the comparable value from Park et al. (1986), and 0.062, the value from Hernández-León and Torres (1997). However, the slope of the $\mathrm{R}_{\mathrm{NH}_{4}+}$ to GDH activiy from Bidigare and King (1981) is about half (0.022). At this stage we do not pretend to think that this relationship is universal and can be applied to all zooplankton. Its variability is still a focus of investigation.

So, why does the GDH activity exceed the $\mathrm{NH}_{4}^{+}$excretion rate by factors ranging from 6 to 18? If we assume that GDH activity sets the upper limit 
for the physiological rate of $\mathrm{NH}_{4}^{+}$excretion and that the $\mathrm{K}_{m}$ is a proxy for the intracellular (in vivo) concentrations of glutamate and $\mathrm{NAD}^{+}$(Cleland, 1963), then other factors are limiting GDH activity to reduce it to the in vivo $\mathrm{NH}_{4}^{+}$excretion rate. In addition to substrate-based regulation, enzyme activity can be modulated by molecules serving as activators or repressors as ADP and GTP serve in the GDH reaction. Consequently, to understand the $\mathrm{GDH} / \mathrm{R}_{\mathrm{NH}_{4}}+$ ratio better, more research is needed involving the role of GTP and ADP as a regulatory molecules under different biological conditions.

The strong correlation between GDH activity and biomass $(\mathrm{r}=0.91, \mathrm{p}$ $<0.01$ ) suggests that GDH is a constitutive enzyme and that GDH activity could serve as an index of zooplankton biomass in a mixed plankton sample. The potential constitutive nature of GDH would predict that its variability in face of environmental fluctuations should be more moderate than the variability of activity in enzymes that are known to be induced or repressed by environmental changes. Assimilatory nitrate reductase, found in marine phytoplankton, is an example of such a sensitive enzyme. In the case of GDH, if it is a permanent component of cells, then accordingly, it will vary with carbon and nitrogen, i. e., biomass. However, as part of a cell's biomass, it would decompose with the cell death, and as a result, GDH would be a good index of living zooplankton biomass. This fact was previously noted with other mitochondrial enzymes, such as ETS (Martínez et al., 2010).

It is well known that metabolic processes, including excretion, scale with body size in an allometric form defined by the equation $\mathrm{M}=\mathrm{aW}^{b}$, where $M$ is the metabolic process, $W$ is body weight and, $a$ and $b$ are constants. In that equality, $b$ constitutes the scalar component which determines the relation- 
ship between metabolic rate and body mass. It is traditionally assumed that $b$ is 0.75 when body mass is expressed as wet mass (Kleiber, 1961; Brown et al., 2007). However, in invertebrates, as in the case of the organism used here, body composition is highly variable with age (Mayzaud, 1986) so that the exponent must be reconsidered in terms of protein mass, which constitutes a relatively constant proportion of weight during growth. In this research we show how $\mathrm{NH}_{4}^{+}$excretion is affected by age with an exponent $b$ of $0.55\left(\mathrm{r}^{2}\right.$ $=0.8$ ). This means that the smaller mysids have higher metabolic rates per unit of protein than do the larger sizes. This $b$ value is slightly lower than the nitrogen-based $b$ values reported by Ikeda and Skjoldal (1989), which ranged from $0.65\left(r^{2}=0.83\right)$ in many species of antarctic zooplankton to $0.8\left(r^{2}=0.6\right)$ in zooplankters from Barents Sea. This dissimilarity can be explained partially by the different specie of zooplankton studied, but also by the more active metabolism in young $L$. lingvura. In contrast, GDH activity is linearly related to protein in the sample $\left(b=0.93, \mathrm{r}^{2}=0.89\right)$, which means that its specific activity is invariant over different body sizes. This finding is in agreement with the behavior of GDH $\left(b=0.98, \mathrm{r}^{2}=0.93\right)$ described by Berges et al. (1990) on different sizes of Artemia franciscana, but somewhat at odds with results by Mayzaud et al. (1994) on the copepod Acartia clausi $\left(b=0.8, \mathrm{r}^{2}=0.77\right)$. However, the latter presents a weaker correlation as a consequence of the use of a narrower range of sizes. Consequently, our resultant $\mathrm{GDH} / \mathrm{R}_{\mathrm{NH}_{4}+}$ ratio shows a small trend to increase as mysids become adults, especially in the initial development stages. This fact suggests that the effect of size acts unevenly on physiological rate and enzymatic activity, since otherwise the slope would be close to zero. Nevertheless, the mean 
ratio obtained in this work is in the range of the other calculations in the literature (table 2). The low value exhibited here is likely favored by the high post-feeding metabolism.

\subsection{The influence of starvation on physiological rates and GDH activity}

A common characteristic in the physiology of zooplankton is the rapid fall of the metabolic rates after depletion of the food source. Since Mayzaud (1976) described a dramatic decrease in nitrogen release after $12 \mathrm{~h}$ of starvation, the same trend has been widely reported in subsequent works (e.g., Ikeda and Skjoldal, 1980). In this study, $\mathrm{NH}_{4}^{+}$excretion diminishes almost three-fold in the first $20 \mathrm{~h}$ to a basal metabolism. Later, after $70 \mathrm{~h}$ of starvation, when a new pulse of food was offered to the mysids, the $\mathrm{NH}_{4}^{+}$excretion increased slightly, although they could not recover the initial values as their physiology was probably injured at this point.

With regard to the GDH activity and its apparent $\mathrm{K}_{m}$, few studies have attempted to evaluate their variability under different trophic conditions. The first study was made by Park (1986) on two species of copepods, but on a larger time-scale and less resolution. Here, GDH seemed to be constant with external changes in food availability, although a small increase in its activity was observed as mysids starved. This might be explained by a reduction in substrate catabolism during the Tricarboxylic Acid (TCA) Cycle leading to decreased formation of GTP, the main inhibitor of GDH. A more pronounced increase in GDH activity per mg of protein under food deprivation was found by Park (1986), who suggested a conversion of GTP into ATP due to the depletion of the high energy forms. However, the range of our results exceeds the variation he measured. The constancy of our GDH data 
explains the occurrence of the highest value of the ratio $\mathrm{GDH} / \mathrm{R}_{\mathrm{NH}_{4}+}$ at the end of the starvation time. The variability in $\mathrm{K}_{m}$ (Table 2) implies internal adjustments of amino acid catabolism as food becomes limiting. A healthy physiological state results in a low apparent $\mathrm{K}_{m}(4.69 \mathrm{mM})$ as a result of rapid protein consumption during growth. However, once the ingested food has been metabolized and no other fuel is available, mysids begin to use their own reservoirs as sources of energy and GDH reduces its affinity for glutamate during the first $24 \mathrm{~h}$ in order to prevent its depletion. Then, the basal metabolism seems to fall to its minimum level and the weak GTP generation via TCA restores a high apparent $\mathrm{V}_{\max }$. However, the in vivo activity is likely much lower due to the absence of substrates at this time.

Furthermore, the changes in excretion rate with starvation are dependent on the body reserves that the mysids metabolize for their energy expenditures. The atomic $\mathrm{R}_{\mathrm{O}_{2}} / \mathrm{R}_{N_{H_{4}}+}$ ratio is used as an indicator of the fuel required for energy. It shows that the substrates oxidized are nearly constant, which is consistent with Kiørboe's et al. (1985) finding in copepods. Values under 13 indicate a reliance on protein (Mayzaud and Conover, 1988), which largely occurs during the experimental period.

\section{Summary}

1. The use of fluorometry promises to improve the sensibility of the GDH assay at least six fold. This improvement should reduce the amount of biomass required for the assay.

2. GDH activity in L. lingvura can account the total physiological $\mathrm{NH}_{4}^{+}$ 
473

excretion. The disparity between the potential and direct measurements suggests a regulation of GDH by a regulatory mechanism stronger than a substrate control.

3. GDH activity varies with biomass, so that it may serve as an index of zooplankton biomass in mixed plankton samples.

4. Body mass affects the $\mathrm{NH}_{4}^{+}$excretion and GDH activity unevenly. This causes an increases in the $\mathrm{GDH} / \mathrm{R}_{\mathrm{NH}_{4}+}$ ratio with biomass.

5. Starvation causes $\mathrm{NH}_{4}^{+}$excretion and GDH activity to diverge more than does body size.

Acknowledgements. We would like to thank to N. Osma and the anonymous reviewers for contributing valuables suggestions which notably improved the manuscript. This research is part of the EXZOME project (CTM 2008 - 01616/MAR), which is supported by the Spanish Science and Education Ministry. I. Fernández-Urruzola received finantial support from the Formation and Perfection of the Researcher Personal Program from the Basque Government. T. Packard was supported by contract EXMAR SE-10/17 (Proyecto Estructurante en Ciencias Marinas). 


\section{References}

\section{References}

Alcaraz, M., Almeda, R., Calbet, A., Saiz, E., Duarte, C.M., Lasternas, S., Agustí, S., Santiago, R., Movilla, J., Alonso, A., 2010. The role of arctic zooplankton in biogeochemical cycles: respiration and excretion of ammonia and phosphate during summer. Polar Biol. 33 (12), 1719 - 1731.

Atkinson, A., Whitehouse, M.J., 2001. Ammonium regeneration by antarctic mesozooplankton: an allometric approach. Mar. Biol. 139, $301-311$.

Batrel, Y., Regnault, M., 1985. Metabolic pathways of ammoniogenesis in the shrimp Crangon crangon L.: possible role of glutamate dehydrogenase. Comp. Biochem. Physiol. 82B (2), $217-222$.

Beckmann, A., Hense, I., 2009. A fresh look at the nutrient cycling in the oligotrophic ocean. Biogeochemistry 96, 1 - 11.

Berges, J.A., Roff, J.C., Ballantyne, J.S., 1990. Relationship between body size, growth rate and maximal enzyme activities in the brine shrimp, Artemia franciscana. Biol. Bull. 179, 287 - 296.

Berges, J.A., Roff, J.C., Ballantyne, J.S., 1993. Enzymatic indices of respiration and ammonia excretion: relationships to body size and food levels. J. Plank. Res. 15 (2), $239-254$.

Bidigare, R.R., 1983. Nitrogen excretion in marine zooplankton. In: E.J. Carpenter, D.G. Capone (Eds.), Nitrogen in the marine environmtent. Academic Press, New York, pp. 385 - 409. 
Bidigare, R.R., King, F.D., 1981. The measurement of glutamate dehydrogenase activity in Praunus flexuosus and its role in the regulation of ammonium excretion. Comp. Biochem. Physiol. 70 (B), 409 - 413.

Bidigare, R.R., King, F.D., Biggs, D.C., 1982. Glutamate dehydrogenase $(\mathrm{GDH})$ and respiratory electron-transport-system (ETS) activities in Gulf of México zooplankton. J. Plank. Res. 4 (4), 895 - 911.

Bode, A., Barquero, S., González, N., Álvarez Ossorio, M.T., Varela, M., 2004. Contribution of heterotrophic plankton to nitrogen regeneration in the upwelling ecosystem of A Coruña (NW Spain). J. Plank. Res. 26 (1), $11-28$.

Bronk, D.A., Glibert, P.M., Ward, B.B., 1994. Nitrogen uptake, dissolved organic nitrogen release and new production. Science 265, 1843 - 1846.

Bronk, D.A., Steinberg, D.K., 2008. Nitrogen regeneration. In: D.G. Capone, D.A. Bronk, M.R. Mulholland, E.J. Carpenter (Eds.), Nitrogen in the marine environment. Academic Press, London, pp. 385 - 467.

Brown, J.H., Allen, A.P., Gillooly, J.F., 2007. The metabolic theory of ecology and the role of body size in marine and freshwater ecolosystems. In: A. Hildrew, D. Raffaelli, R. Edmonds Brown (Eds.), Body size: the structure and function of aquatic ecosystems. Cambridge University Press, Cambridge, pp. $1-15$.

Campbell, R.W., Boutillier, P., Dower, J.F., 2004. Ecophysiology of overwintering in the copepod Neocalanus plumchrus: changes in lipid and protein contents over a seasonal cycle. Mar. Ecol. Prog. Ser. 280, 211 - 226. 
Cleland, W.W., 1963. The kinetics of enzyme - catalyzed reactions with two or more substrates or products: I. Nomenclature and rate equations. Biochim. Biophys. Acta 67, $104-137$.

Domingues, P.M., Turk, P.E., Andrade, J.P., Lee, P.G., 1998. Pilot-scale production of mysid shrimp in a static water system. Aquacult. Int. 6, 387 $-402$.

Dugdale, R.C., Goering, J.J., 1967. Uptake of new and regenerated forms of nitrogen in primary productivity. Limnol. Oceanogr. 12, $196-206$.

Eppley, R.W., Peterson, B.J., 1979. Particulate organic matter flux and planktonic new production in the deep ocean. Nature 282, $677-680$.

Falkowski, P.G., Barber, R.T., Smetacek, V., 1998. Biogeochemical controls and feedbacks on ocean primary production. Science 281, $200-206$.

Friedmann, H.C., 1981. Enzymes, Benchmark papers in biochemistry, vol. I. Hutchinson Ross Publishing Company, Pennsylvania, 716 pp.

Glibert, P.M., 1993. The interdependence of uptake and release of $\mathrm{NH}_{4}^{+}$and organic nitrogen. Mar. Microb. Food Webs 7 (1), $53-67$.

Glibert, P.M., 1998. Interactions of top-down and bottom-up control in planktonic nitrogen cycling. Hydrobiologia 363, $1-12$.

Glibert, P.M., Lipschultz, F., McCarthy, J.J., Altabet, M.A., 1982. Isotope dilution models of uptake and remineralization of ammonium by marine plankton. Limnol. Oceanogr. 27 (4), 639 - 650. 
Harrison, W.G., 1992. Regeneration of nutrients. In: P.G. Falkowski, A.D. Woodhead (Eds.), Primary productivity and biogeochemical cycles in the Sea. Plenum press, New York, pp. 385 - 409.

Harrison, W.G., Platt, T., Lewis, M.R., 1987. F-ratio and its relationship to ambient nitrate concentration in coastal waters. J. Plank. Res. 9 (1), 235 $-248$.

Hernández-León, S., Fraga, C., Ikeda, T., 2008. A global estimation of mesozooplankton ammonium excretion in the open ocean. J. Plank. Res. 30 (5), $577-585$.

Hernández-León, S., Torres, S., 1997. The relationship between ammonia excretion and GDH activity in marine zooplankton. J. Plank. Res. 19 (5), $587-601$.

Herrera, A., Gómez, M., Molina, L., Otero, F., Packard, T., 2011. Rearing techniques and nutritional quality of two mysids from Gran Canaria (Spain). Aquac. Res. 42, $677-683$.

Holmes, R.M., Aminot, A., Kérouel, R., Hooker, B.A., Peterson, B.J., 1999. A simple and precise method for measuring ammonium in marine and freshwater ecosystems. Can. J. Fish. Aquat. Sci. 56, $1801-1808$.

Ikeda, T., 1985. Metabolic rates of epipelagic marine zooplankton as a function of body mass and temperature. Mar. Biol. 85, $1-11$.

Ikeda, T., Skjoldal, H.R., 1980. The effect of laboratory conditions on the extrapolation of experimental measurements to the ecology of marine zoo- 
plankton VI. Changes in physiological activities and biochemical components of Acetes sibogae australis and Acartia australis after capture. Mar. Biol. 58 (4), $285-293$.

Ikeda, T., Skjoldal, H.R., 1989. Metabolism and elemental composition of zooplankton from the Barents Sea during early arctic summer. Mar. Biol. $100,173-183$.

Ikeda, T., Torres, J.J., Hernández León, S., Geiger, S.P., 2000. Metabolism. In: R.P. Harris, P.H. Wiebe, J. Lenz, H.R. Skjoldal, M. Huntley (Eds.), ICES zooplankton methodology manual. Academic Press, London, pp. 455 $-532$.

Jeffries, H.P., 1969. Seasonal composition of temperate plankton communities: free amino acids. Limnol. Oceanogr. 14, $41-52$.

King, F.D., Cucci, T.L., Townsend, D.W., 1987. Microzooplankton and macrozooplancton glutamate dehydrogenase as indices of the relative contribution of these fractions to ammonium regeneration in the Gulf of Maine. J. Plank. Res. 9 (2), 277 - 289.

Kiørboe, T., Møhlenberg, F., Hamburger, K., 1985. Bioenergetics of the planktonic copepod Acartia tonsa: relation between feeding, egg production and respiration, and composition of specific dynamic action. Mar. Ecol. Prog. Ser. 26, $85-97$.

Kleiber, M., 1961. The fire of life: an introduction to animal energetics. John Wiley and Sons, Inc., New York, 454 pp. 
Lindén, E., Kuosa, H., 2004. Effects of grazing and excretion by pelagic mysids (Mysis spp.) on the size structure and biomass of the phytoplankton community. Hidrobiologia 514, $73-78$.

Lowry, O.H., Rosebrough, N.J., Farr, A.L., Randall, R.J., 1951. Protein measurement with the folin phenol reagent. J. Biol. Chem. 193, $265-275$.

Lussier, S.M., Kuhn, A., Chammas, M.J., Sewall, J., 1988. Techniques for the laboratory culture of Mysidopsis species (Crustacea: Mysidacea). Environ. Toxicol. Chem. 7, 969 - 977.

Martínez, I., Gómez, M., Packard, T.T., 2010. Potential respiration is a better respiratory predictor than biomass in young Artemia salina. J. Exp. Mar. Biol. Ecol. 390, 78 - 83.

Mayzaud, P., 1976. Respiration and nitrogen excretion of zooplankton. IV. The influence of starvation on the metabolism and the biochemical composition of some species. Mar. Biol. 37, $47-58$.

Mayzaud, P., 1986. Enzymatic measurements of metabolic processes concerned with respiration and ammonia excretion. In: E.D.S. Corner, S.C.M. O'Hare (Eds.), Biological Chemistry of Copepods. Clarendon Press, Oxford, pp. $226-259$.

Mayzaud, P., Biggs, D.G., Roche Mayzaud, O., 1994. Short-term variability of metabolic and digestive enzyme activity in naturally occurring populations of adult copepod Acartia clausi. Ecoscience 1 (3), 195 - 207.

Mayzaud, P., Conover, R.J., 1988. 0:N atomic ratio as a tool to describe zooplankton metabolism. Mar. Ecol. 45, 289 - 302. 
Miller, C.A., Roman, M.R., 2008. Effects of food nitrogen content and concentration on the forms of nitrogen excreted by the calanoid copepod, Acartia tonsa. J. Exp. Mar. Biol. Ecol. 359, 11 - 17.

Park, Y.C., 1986. Impact of starvation and feeding experiments on ammonium excretion and glutamate dehydrogenase activity of zooplankton. Kor. Biochem. J. 19 (1), $251-256$.

Park, Y.C., Carpenter, E.J., Falkowski, P.G., 1986. Ammonium excretion and glutamate dehydrogenase activity of zooplankton in Great South Bay, New York. J. Plank. Res. 8 (3), 489 - 503.

Regnault, M., 1987. Nitrogen excretion in marine and fresh-water crustacea. Biol. Rev. 62, $1-24$.

Rutter, W.J., 1967. Protein determination in embryos. In: F.H. Wilt, N.V. Wessels (Eds.), Methods in developmental biology. Academic Press, London, pp. $671-684$.

Saba, G.K., Steinberg, D.K., Bronk, D.A., 2009. Effects of diet on release of dissolved organic and inorganic nutrients by the copepod Acartia tonsa. Mar. Ecol. Prog. Ser. 386, 147 - 161.

Segel, I.H., 1993. Enzyme Kinetics. Behaviour and analysis of rapid equilibrium and steady-state enzyme systems. Wiley Classics Library ed. John Wiley and Sons, Inc., New York, 957 pp.

Steinberg, D.K., Saba, G.K., 2008. Nitrogen consumption and metabolism in marine zooplankton. In: D.G. Capone, D.A. Bronk, M.R. Mulholland, E.J. 
${ }_{642}$ Carpenter (Eds.), Nitogen in the marine environment. Academic Press, ${ }_{643}$ London, pp. $1135-1196$.

${ }_{644}$ Yool, A., Martin, A.P., Fernández, C., Clark, D.R., 2007. The significance ${ }_{645}$ of nitrification for oceanic new production. Nature 447, $999-1002$.

${ }_{646}$ Zehr, J.P., Kudela, R.M., 2011. Nitrogen cycle of the open ocean: from genes 647 to ecosystems. Annu. Rev. Mar. Sci. 3, $197-225$.

Zehr, J.P., Ward, B.B., 2002. Nitrogen cycling in the ocean: new perspectives 649 on processes and paradigms. Appl. Environ. Microbiol. 68 (3), 1015 - 1024. 


\section{List of Captions (Tables and Figures)}

Table 1. Effect of starvation on the Michaelis constants, and on the $\mathrm{GDH} / \mathrm{R}_{\mathrm{NH}_{4}+}$ and $\mathrm{R}_{\mathrm{O}_{2}} / \mathrm{R}_{\mathrm{NH}_{4}}+$ ratios.

Table 2. Values of the GDH activity to $\mathrm{NH}_{4}^{+}$excretion ratios reported in the literature from zooplankters of different regions. Notice that the value of this work comes from the mean of the values measured in the well fed mysids.

Fig. 1. (A) Effect of enzyme concentration (mg protein per assay) on GDH activities measured spectrophotometrically and (B) spectrofluorometrically. (C) The correspondence between the activities $\left(\mu \mathrm{mol} \mathrm{NH}+\mathrm{NH}_{4}^{+} \cdot \mathrm{h}^{-1}\right)$ obtained from the spectrophotometry (x-axis) and from the spectrofluorometry (y-axis). None of the slopes are significantly different from 1 and none of intercepts are significantly different from zero $(\mathrm{p}<0.05)$. Each data point represents the mean of triplicates, with the standard deviations calculated for both techniques.

Fig. 2. Enzyme kinetics of GDH exhibited in a well-fed mysid for the substrates of the reaction, glutamate (left) and $\mathrm{NAD}^{+}$(rigth). Top: MichaelisMenten curves. Bottom: Kinetic parameters extracted from the doublereciprocal transformations. Each $\mathrm{y}$-axis intersect is equal to $1 / \mathrm{V}_{\max }$, and the regression slopes are defined by $\mathrm{K}_{m} / \mathrm{V}_{\max }$. The data represent the mean of triplicate analyses. 
Fig. 3. (A) Protein mass, (B) $\mathrm{NH}_{4}^{+}$excretion rates and (C) GDH activities per mysid over the month of experimentation.

Fig. 4. Linear regression between GDH activity and physiological $\mathrm{NH}_{4}^{+}$ excretion per mysid.

Fig. 5. (A) $\mathrm{NH}_{4}^{+}$excretion rates (per mg protein), (B) GDH activities (per mg protein), and (C) the resultant $\mathrm{GDH} / \mathrm{R}_{N H_{4}^{+}}$ratios, all as a function of age. The equations in $\mathrm{A}$ and $\mathrm{C}$ (given in graphs) are significant at $\mathrm{p}<$ 0.01. The slope in B is not significantly different from zero $(\mathrm{p}<0.01)$.

Fig. 6. Log-transformed $\mathrm{NH}_{4}^{+}$excretion rates (filled circles) and GDH activities (open circles) versus log-transformed protein mass.

Fig. 7. Impact of food deprivation on: (A) $\mathrm{NH}_{4}^{+}$excretion rates and (B) GDH activities of L. lingvura. The vertical broken line at $70 \mathrm{~h}$ represents the time in which one pulse of food was offered to the mysids again. Thus, filled circles represents the starved mysids, while open circles refers to the experimental organisms which were fed again. However, only the starvation experimental data were considered in calculating the curves. The equation in $\mathrm{A}$ (given in graph) is significant at $\mathrm{p}<0.01$. The slope in B is not significantly different from zero $(\mathrm{p}<0.01)$. 
Table 1:

\begin{tabular}{|c|c|c|c|c|}
\hline $\begin{array}{l}\text { Starvation } \\
\qquad(\mathrm{h})\end{array}$ & $\begin{array}{l}\text { Apparent } \mathrm{K}_{m} \\
(\mathrm{mM})\end{array}$ & $\mathrm{GDH} / \mathrm{R}_{N H_{4}+}$ & $\begin{array}{c}\mathrm{O}_{2} \text { consumption } \\
\left(\mu \mathrm{mol} \mathrm{O} \mathrm{O}_{2} \cdot \mathrm{h}^{-1} \cdot \mathrm{mg} \text { protein }^{-1}\right)\end{array}$ & $\mathrm{R}_{O_{2}} / \mathrm{R}_{N_{H_{4}}}$ \\
\hline 4 & $4.69 \pm 0.69$ & $11.23 \pm 4.46$ & $0.61 \pm 0.09$ & $4.57 \pm 1.90$ \\
\hline 10 & $12.10 \pm 5.90$ & $9.74 \pm 2.98$ & $1.29 \pm 0.32$ & $6.66 \pm 1.65$ \\
\hline 18 & $8.55 \pm 4.04$ & $11.14 \pm 5.93$ & $0.50 \pm 0.15$ & $5.51 \pm 2.47$ \\
\hline 26 & $19.44 \pm 10.80$ & $30.87 \pm 25.28$ & $0.60 \pm 0.11$ & $11.51 \pm 1.73$ \\
\hline 42 & $4.67 \pm 0.79$ & $16.28 \pm 1.55$ & $0.20 \pm 0.18$ & $2.13 \pm 0.29$ \\
\hline 54 & $5.04 \pm 0.27$ & $64.72 \pm 51.3$ & $0.22 \pm 0.22$ & $7.07 \pm 3.25$ \\
\hline 68 & 2.84 & 102.41 & 0.24 & 12.90 \\
\hline 72 & $4.89 \pm 3.45$ & $67.89 \pm 29.50$ & $0.55 \pm 0.05$ & $15.49 \pm 8.60$ \\
\hline 76 & $5.95 \pm 2.48$ & $39.10 \pm 5.09$ & $0.74 \pm 0.43$ & $14.12 \pm 2.96$ \\
\hline 82 & $6.25 \pm 2.51$ & $89.10 \pm 34.58$ & $0.59 \pm 0.36$ & $47.20 \pm 15.50$ \\
\hline
\end{tabular}


Table 2:

\begin{tabular}{cccc}
\hline Sample & Location & GDH $/ \mathrm{R}_{\mathrm{NH}_{4}}$ & Reference \\
\hline Leptomysis lingvura sp. $(\mathrm{n}=41)$ & Canary Islands & $9.64 \pm 4.81$ & Present work \\
Neocalanus plumchrus & Strait of Georgia & $15.30 \pm 4.30$ & Campbell et al. (2004) \\
Mixed macrozooplankton $(\mathrm{n}=59)$ & Canary Islands & $13.89 \pm 10.36$ & Hernández-León and Torres (1997) \\
Mixed zooplankton $(\mathrm{n}=8)$ & Gulf of Maine & $23.40 \pm 4.00$ & King et al. (1987) \\
Mixed macrozooplankton $(\mathrm{n}=10)$ & Great South Bay & $18.18 \pm 6.72$ & Park et al. (1986) \\
Mixed zooplankton $(\mathrm{n}=5)$ & Gulf of Mexico & $18.70 \pm 4.30$ & Bidigare et al. (1982) \\
Calanus finmarchicus $(\mathrm{n}=10)$ & Gulf of Maine & $16.80 \pm 2.60$ & Bidigare and King (1981) \\
\hline
\end{tabular}



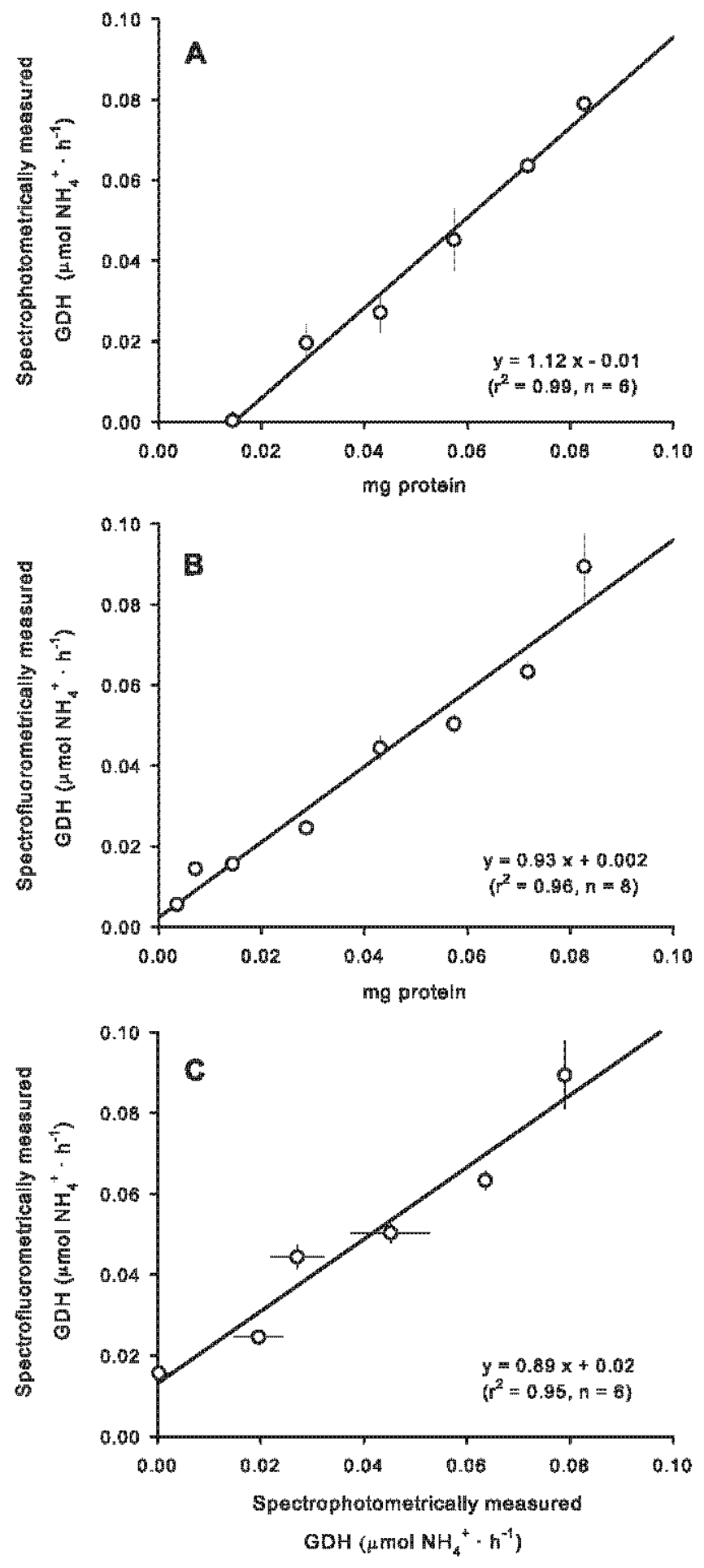

Figule 1: 

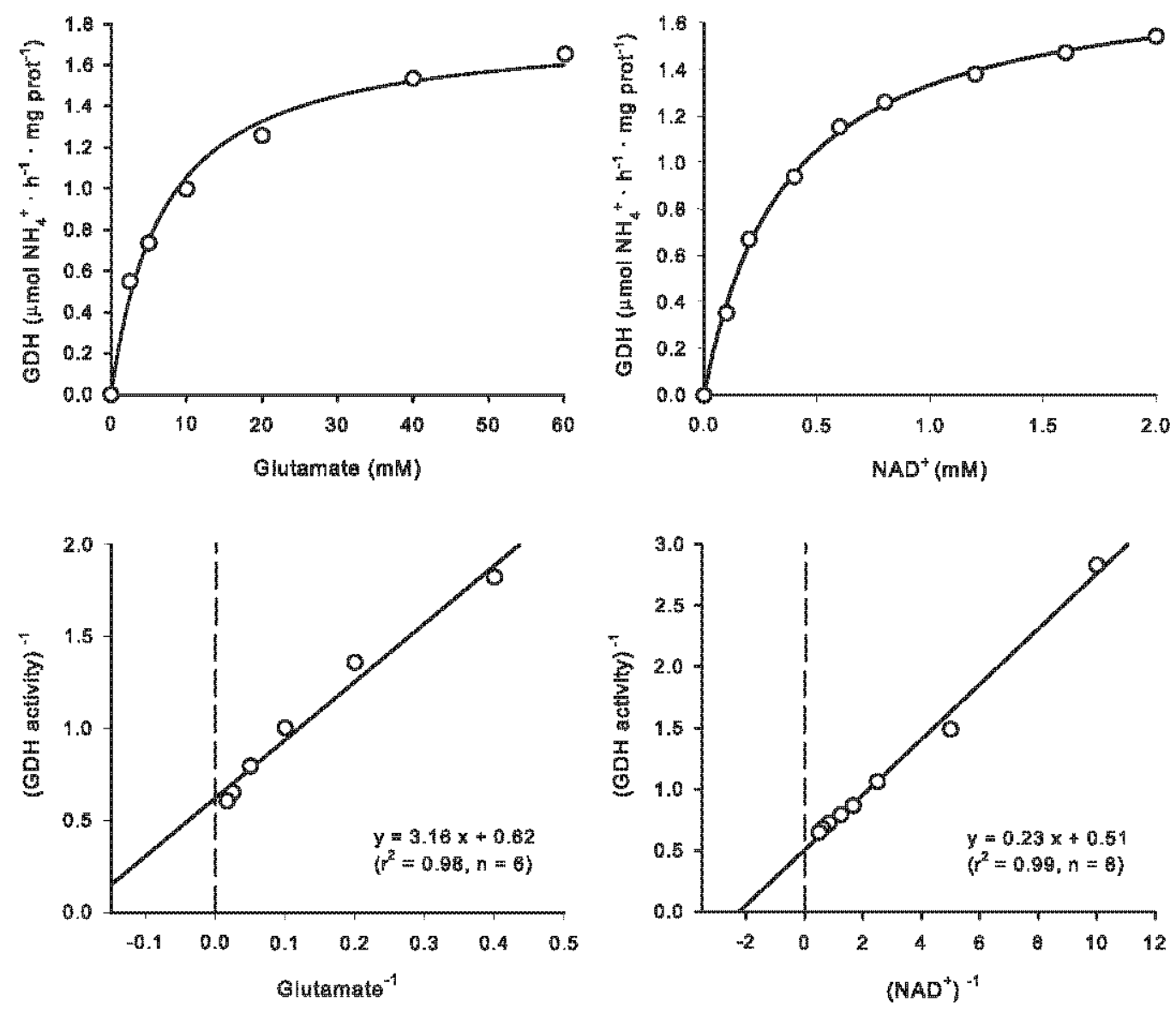

Figư⿰亻弋 2: 

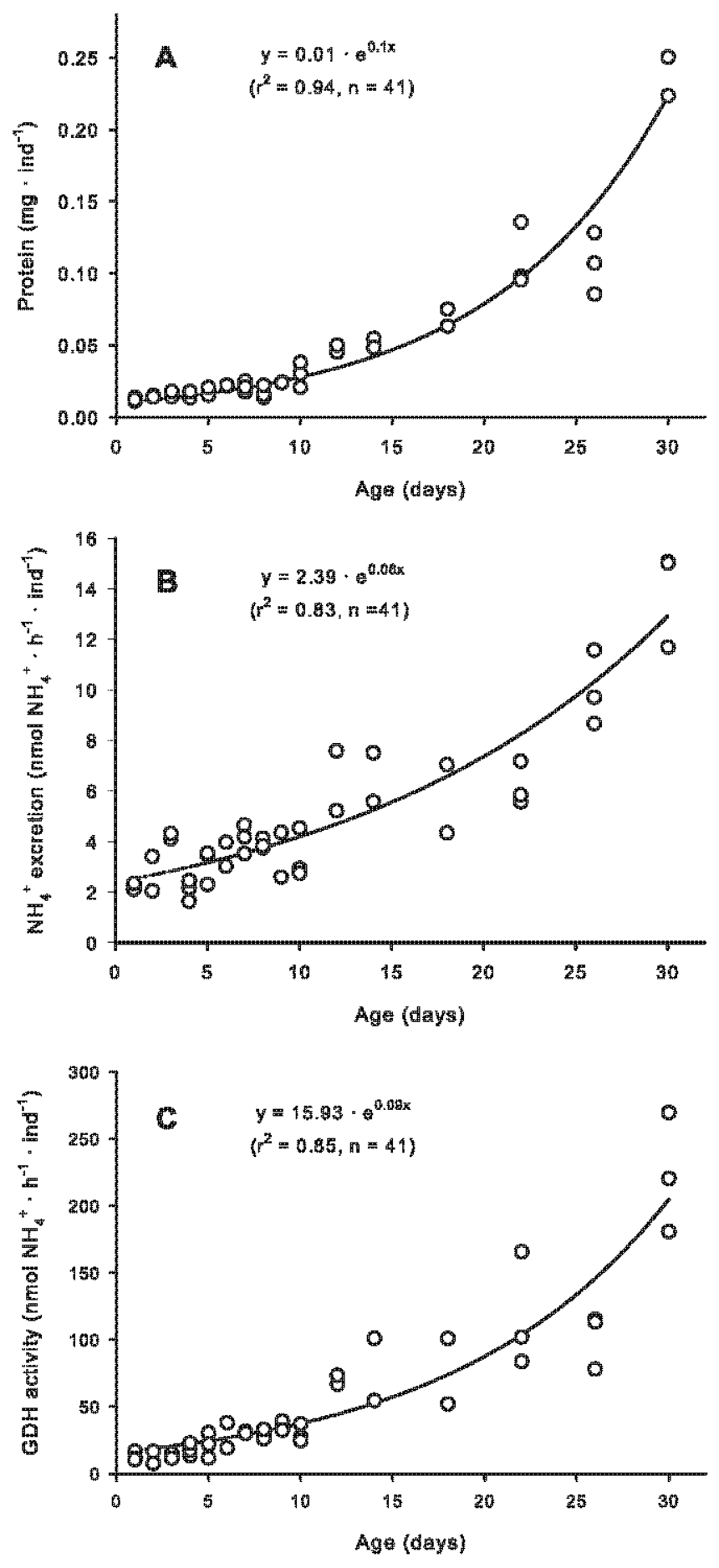

Figute 3: 


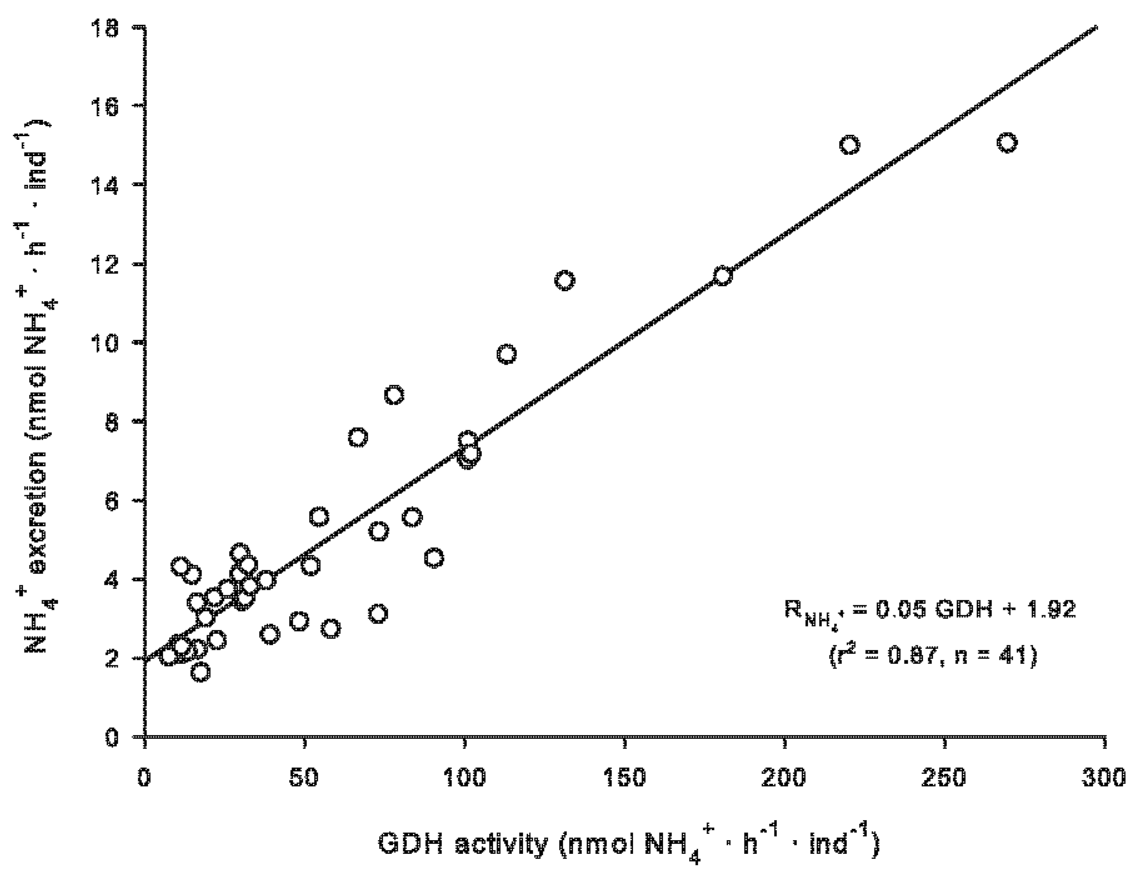

Figure 4: 

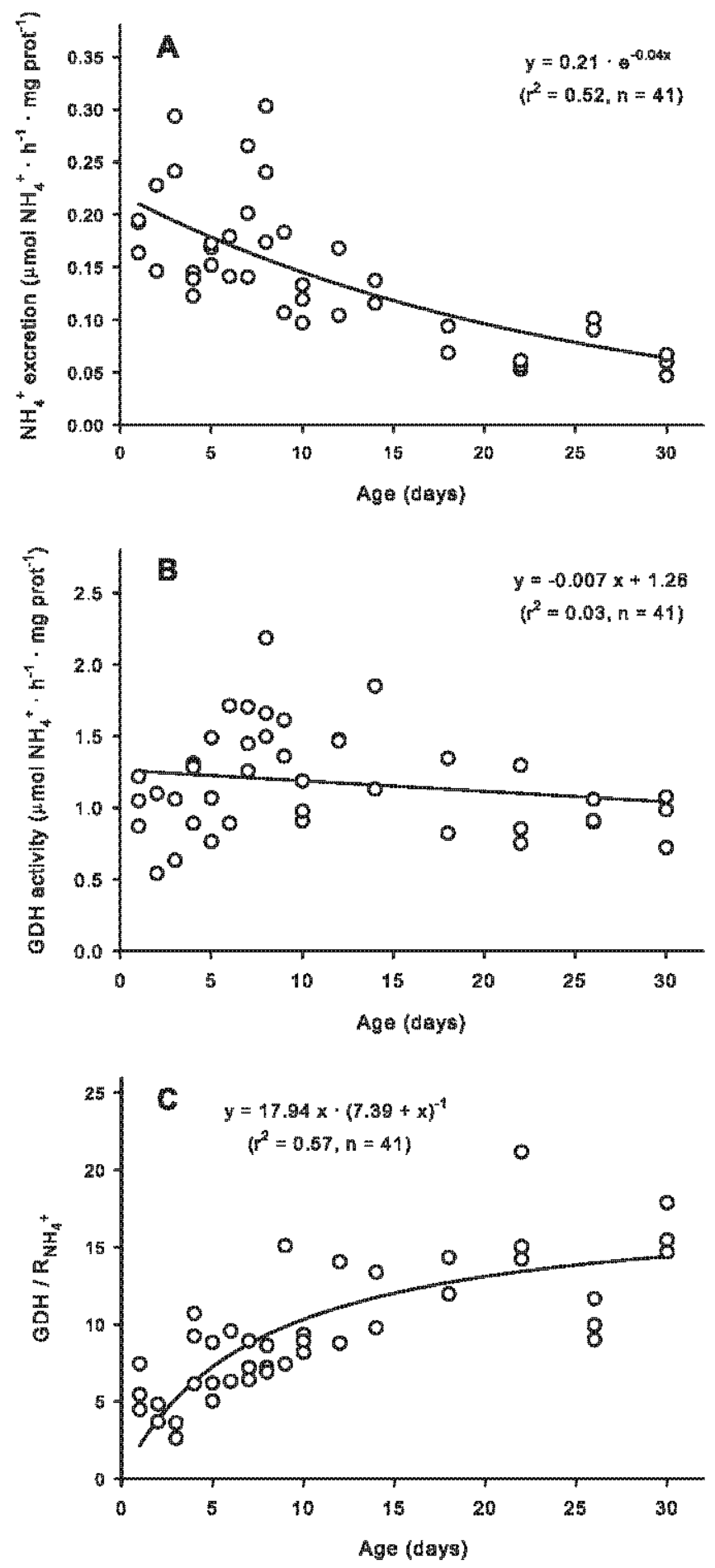

Figure 5: 


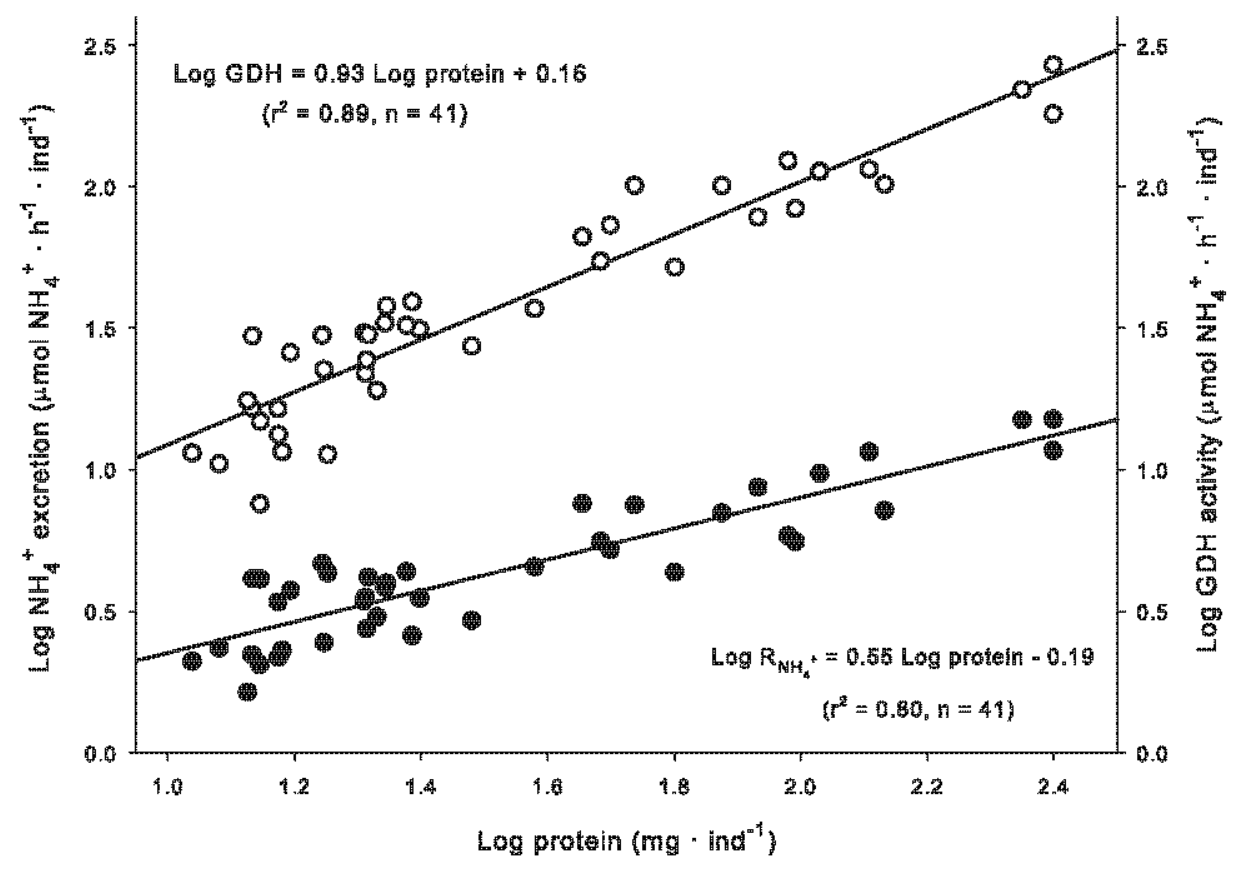

Figure 6: 

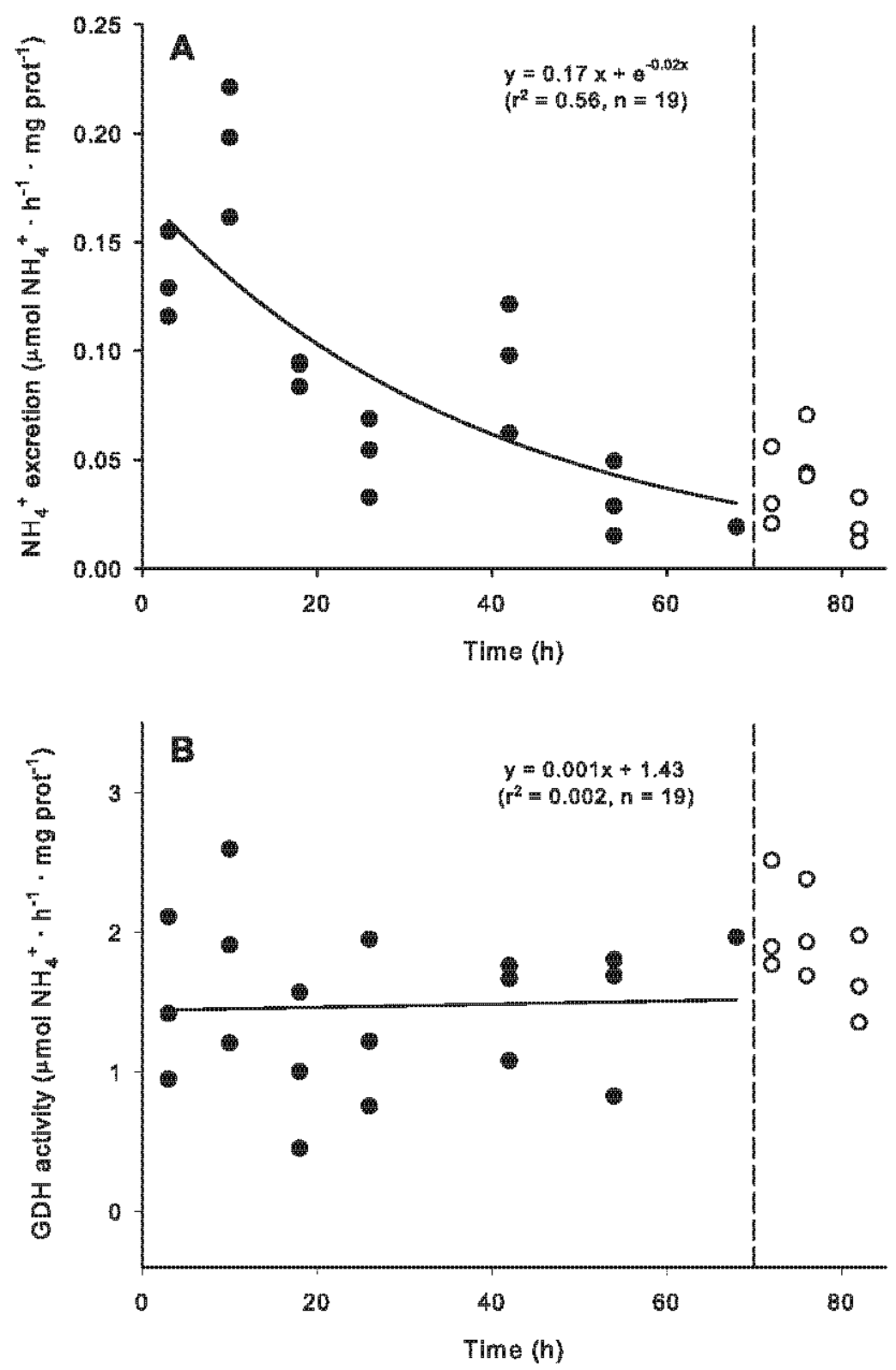

Figure 7: 